\title{
Therapeutic Hypothermia in Perinatal Asphyxia
}

\author{
Rabindran', Gedam DS ${ }^{2}$ \\ ${ }^{1}$ Dr. Rabindran, Consultant Neonatologist, Billroth Hospital, Chennai, India, Dr D Sharad Gedam, Professor of \\ Pediatrics, L N Medical college, Bhopal, MP, India
}

Address for Correspondence: Dr Rabindran, E mail: rabindranindia@yahoo.co.in

\begin{abstract}
Therapeutic hypothermia for infants with perinatal asphyxia has been studied in several randomised controlled trials. There is convincing evidence that moderate therapeutic hypothermia $\left(33-34^{\circ} \mathrm{C}\right.$ for $\left.72 \mathrm{~h}\right)$, when initiated within $6 \mathrm{~h}$ after birth among term \& near-term infants ( $\geq 35$ weeks) with moderate to severe HIE reduces the risk of death or major disability $\&$ increases the rate of disability-free survival at 6-7 years of age
\end{abstract}

Key words: Therapeutic hypothermia, Asphyxia, perinatal asphyxia.

\section{Introduction}

Asphyxia is a major problem worldwide as $10 \%$ to $60 \%$ of affected infants die, \& at least $25 \%$ of survivors have long-term neurodevelopmental sequelae. Therapeutic hypothermia for infants with perinatal asphyxia has been studied in several randomised controlled trials. There is convincing evidence that moderate therapeutic hypothermia $\left(33-34^{\circ} \mathrm{C}\right.$ for $\left.72 \mathrm{~h}\right)$, when initiated within 6 $h$ after birth among term \& near-term infants $(\geq 35$ weeks) with moderate to severe HIE reduces the risk of death or major disability \& increases the rate of disability-free survival at 6-7 years of age. Hypothermia results in a graded reduction in cerebral metabolism, suppresses apoptotic processes \& also suppresses the release of pro-inflammatory cytokines \& interleukins. The target body temperature is $34.5{ }^{\circ} \mathrm{C}$ for selective head cooling $\& 33.5{ }^{\circ} \mathrm{C}$ for total body cooling. Active cooling should be done for 72 hours \& then gradual rewarming is done over 12 hours. Whole body cooling provides homogeneous cooling whereas selective head cooling provides greater cooling to the periphery of the brain than to the deeper brain structures. Though there were no reported serious adverse effects in the initial pilot studies of hypothermia in newborns, potential side effects reported later include bradycardia, arrhythmias, Hypotension, Reduction in surfactant production, Altered coagulation cascade, Thrombocytopaenia, Leukopaenia, lactic acidosis,

Manuscript received: $19^{\text {th }}$ Jan 2016

Reviewed: $01^{\text {st }} \mathrm{Feb} 2016$

Author Corrected; $10^{\text {th }} \mathrm{Feb} 2016$

Accepted for Publication: 20 $0^{\text {th }} \mathrm{Feb} 2016$
Hypokalaemia \& Hypoglycaemia. With the development of newer modes of servo controlled hypothermia devices the cerebral insult due to asphyxia can be reduced \& severe sequlae of HIE can be prevented.

Asphyxia-Problem Statement: Perinatal asphyxia affects 3-5 newborns per 1000 live births with subsequent moderate or severe hypoxic ischaemic encephalopathy (HIE) in 0.5 to 1 per 1000 live births $[1,2]$. HIE is a major problem worldwide as $10 \%$ to $60 \%$ of affected infants die, and at least $25 \%$ of survivors have long-term neurodevelopmental sequelae $[3,4]$. Globally, perinatal asphyxia is responsible for 42 million disability life adjusted years, double that due to diabetes \& three quarters of that due to HIV/AIDS [5]. Almost one quarter of the world's 4 million annual neonatal deaths are caused by perinatal asphyxia [6]. These account for as many deaths as does malaria.

Therapeutic Hypothermia-Evidence: Therapeutic hypothermia for infants with perinatal asphyxia has been studied in several randomised controlled trials (RCT) [7-10]. Meta-analyses show that therapeutic hypothermia increases survival with normal neurological function (pooled risk ratio of 1.53) with a number needed to treat (NNT) of $8 \&$ in survivors reduces the rates of severedisability \& cerebral palsy $[11,12]$. A systematic review of three trials showed a significant reduction of combined rate of death \& 
severe disability with NNT of $9 \&$ increased normal survival (survival without cerebral palsy \& with MDI \& PDI $>84 \&$ normal vision \& hearing) with a NNT of 8 [12]. In a Cochrane review of 11 RCT comprising 1505 infants with moderate/severe encephalopathy \&evidence of intrapartum asphyxia, therapeutic hypothermia resulted in a statistically significant reduction in combined outcome of mortality or major neurodevelopmental disability to 18 months of age (RR 0.75,RD -0.15); NNT for an additional beneficial outcome being 7 . Cooling resulted in statistically significant reductions in mortality (RR 0.75, RD -0.09);

NNT $11 \quad \& \quad$ significant reductions in neurodevelopmental disability among survivors (RR 0.77, RD -0.13); NNT 8 [13]. A 2013 Cochrane review found that therapeutic hypothermia is useful in full term babies with encephalopathy [13]. There is convincing evidence that moderate therapeutic hypothermia (33$34^{\circ} \mathrm{C}$ for $72 \mathrm{~h}$ ), when initiated within $6 \mathrm{~h}$ after birth among term \& near-term infants ( $\geq 35$ weeks) with moderate to severe HIE reduces the risk of death or major disability $[12,13,14] \&$ increases the rate of disability-free survival at 6-7 years of age $[10,15]$.

Hypothermia Trials: Cool Cap trial used selective head cooling with mild systemic hypothermia (rectal temperature $34-35^{\circ} \mathrm{C}$ ) commenced within 5.5 hours of age for 72 hours \& showed an independent protective effect of hypothermia on the primary outcome of death or disability at 18 months (odds ratio 0.52) [7,16]. NICHD trial of whole body cooling (oesophageal temperature $33.5^{\circ} \mathrm{C}$ for $72 \mathrm{~h}$ ) showed a significant reduction in the risk of death \& moderate to severe disability at 18 months in the hypothermia group [8] TOBY trial of whole body cooling (rectal temperature $33.5^{\circ} \mathrm{C}$ for $72 \mathrm{~h}$ ) showed a significant improvement in neurologic outcome in survivors from the hypothermic group [10]. Neo Neuro Network study [17] \& ICE trial [18] further support a beneficial effect of hypothermia.

Proposed Mechanisms of Hypothermia: Hypothermia results in a graded reduction in cerebral metabolism by approximately $5 \%$ for each $1{ }^{\circ} \mathrm{C}$ decrease in body temperature $[3,4,7,12,19]$ that slows cell depolarization, reduces accumulation of excito-toxic neurotransmitters (aspartate, glutamate, dopamine) [20-22] \& suppresses oxygen free radical release [23] as well as lipid peroxidation of cell membranes thereby lowering production of toxic nitric oxide (NO) \& free radicals [23]. It suppresses apoptotic processes in the developing brain via inhibition of caspase enzymes [13,24-26].
Cytochrome C translocation is diminished by hypothermia $[26,27] \&$ there is increased expression of anti-apoptotic protein BCl-2 [28]. It also suppresses the release of pro-inflammatory cytokines \& interleukins during reperfusion injury phase, thereby reducing direct neurotoxicity via suppression of microglial activation $[29,30]$.The simultaneous increase in cytotoxic oedema\& loss of cerebral cortical activity that accompanies secondary energy failure is also prevented [31].

Cooling Protocol: The target body temperature is 34.5 ${ }^{\circ} \mathrm{C}$ for selective head cooling \& $33.5{ }^{\circ} \mathrm{C}$ for total body cooling. Temperatures lower than $32{ }^{\circ} \mathrm{C}$ are less neuroprotective $\&$ temperatures below $30{ }^{\circ} \mathrm{C}$ are very dangerous with severe complications [32]. Therapeutic hypothermia must be started within the first $6 \mathrm{~h}$ after birth which is the therapeutic window for hypoxicischemic event. Active cooling should be done for 72 hours from the initiation of cooling with very strict control of newborn's body temperature. Then gradual rewarming is done over 12 hours by increasing temperature by $0.5^{\circ} \mathrm{C}$ every 2 hours.

\section{Eligibility/criteria for therapeutic hypothermia:}

1) More than 35 weeks of gestation.

2) Less than 6 hours of age.

3) Presence of evidence of asphyxia - at least two of the following four criteria:

i) Apgar less than 6 at 10 min or continued need for resuscitation with positive pressure ventilation with / without chest compressions at $10 \mathrm{~min}$ of age.

ii) Any acute perinatal event that may result in HIE (i.e. Abruption placenta, cord prolapse, severe foetal heart rate abnormality).

iii) Cord $\mathrm{pH}$ less than 7.0 or base deficit of 12 or more.

iv) If cord $\mathrm{pH}$ is unavailable, arterial $\mathrm{pH}$ less than 7.0/ BE more than $12 \mathrm{mmol} / \mathrm{L}$ within $60 \mathrm{~min}$.

4) Clinically defined moderate or severe HIE (stage 2 or 3 based on modified Sarnat Classification).

5) Moderate to severely abnormal background activity on amplitude-integrated EEG (.i.e. discontinuous, burst suppression or low voltage $+/$ - seizure activity).

Modes of Cooling: Therapeutic hypothermia lowers the temperature of vulnerable deep brain structures, basal 
ganglia to $32-34{ }^{\circ} \mathrm{C}$. Brain hypothermia can be achieved by cooling the body, cooling the head selectively, or by cooling the head \& body together. Whole body cooling provides homogeneous cooling to all brain structures, including the peripheral \& central brain regions, whereas selective head cooling provides greater cooling to the periphery of the brain than to the deeper brain structures [33]. The combination of head\& body cooling minimises the temperature gradients across the brain \& also facilitates the cooling of the deeper regions. To provide adequate neuroprotection with minimal risk of systemic adverse effects, ideally the brain only should be cooled. However, in view of a temperature gradient between the cerebral cortex \& deep grey nuclei, i.e. structures that are often affected in acute asphyxia, mild systemic hypothermia $\left(34.5^{\circ} \mathrm{C}\right)$ is preferred to limit the steepness of the intra-cerebral gradient.

Devices for Cooling: Various devices have been used for therapeutic hypothermia.

1) Selective head cooling by circulating water at $10^{\circ} \mathrm{C}$ through a coil of tubing wrapped around the head (CoolCap). A servo-controlled overhead heater was used to maintain rectal temperature at $34^{\circ} \mathrm{C}$ to $35^{\circ} \mathrm{C}$ [16].

2) Placing a cap formed from cooled packs around the head at a temperature of $10^{\circ} \mathrm{C}$, to maintain a nasopharyngeal temperature of $34^{\circ} \mathrm{C}$ to $35^{\circ} \mathrm{C}$ [34].

3) Placing infant on a water blanket pre-cooled to $5^{\circ} \mathrm{C}$ \& the blanket temperature was servo-controlled to maintain an oesophageal temperature of $33.5^{\circ} \mathrm{C}$ [8].

4) Blowing cool air through a translucent perforated paper blanket placed over the infant to achieve the target rectal temperature between $33.0^{\circ} \mathrm{C}$ to $34.0^{\circ} \mathrm{C}$ [16]. Nowadays hypothermia is maintained with servo controlled systems aimed at reducing fluctuations in body temperature.

Adverse Effects of Cooling: There were no reported serious adverse effects in initial four pilot studies of hypothermia in newborns [35-38]. The potential side effects reported later include Delayed intracardiac conduction with sinus bradycardia $[39,40]$, Prolonged QT interval, Ventricular arrhythmias, Reduced cardiac output, Hypotension, Hypertension, Reduction in surfactant production, Increase in pulmonary vascular resistance, Increase in oxygen consumption \& oxygen requirement, Altered coagulation cascade\& viscosity leading to coagulopathy that may be complicated by thrombus or haemorrhage, Anaemia, Thrombocytopaenia, Leukopaenia with increased risk of sepsis, Renal impairment, Metabolic \& lactic acidosis, Hypokalaemia, Hypoglycaemia, Impaired liver function, Increase in vascular resistance, Platelet dysfunction, Excessive fibrinolytic activity, Diuresis due to suppression of antidiuretic hormones, Pulmonary hypertension, Impaired leukocyte mobility \&phagocytosis [16]. Adverse effects, such as sinus bradycardia, increased blood pressure and increased oxygen requirement, were all transient and reversible with re-warming [36]. Cooling in the presence of infection might be deleterious as hypothermia may impair innate immune function, including neutrophil migration and function [41]. When lowering the body temperature, blood becomesmore viscous \& the solubility of the gases in theblood increases; for example, in vivo values at $33.5^{\circ} \mathrm{C}$ of $\mathrm{PaCO} 2$ are approximately 0.83 the valueread at $37^{\circ} \mathrm{C}$. Correcting for temperature may resultin an increase in $\mathrm{PaCO} 2$ with a resultant increasein cerebral blood flow, whereas notcorrecting may result in the opposite effect, i.e.hypocapniainduced vasoconstriction. During hypothermia, there may be an increasedrisk of endotracheal tube obstruction due to stickysecretions which can be avoided by setting the temperatureof the humidifier at $37^{\circ} \mathrm{C}$. During re-warming, seizures, hypotension [42], hypoglycaemia or hypokalemia can occur.

\section{Conclusion}

Therapeutic hypothermia is a proven therapy in perinatal asphyxia provided prompt selection of babies $\&$ religious monitoring of temperature is done. Strict surveillance for the development of adverse effects is mandatory. With the development of newer modes of servo controlled hypothermia devices the cerebral insult due to asphyxia can be reduced $\&$ severe sequlae of HIE can be prevented.

Funding: No funding sources

Conflict of interest: None declared

Ethical approval: The study was approved by the Institutional Ethics Committee.

\section{References}

1. Costello AM, Manandhar DS. Perinatal asphyxia in less developed countries. Arch Dis Child Fetal Neonatal Ed. 1994 Jul;71(1):F1-3. 
2. Snowden JM, Cheng YW, Kontgis CP, Caughey AB. The association between hospital obstetric volume and perinatal outcomes in California. Am J Obstet Gynecol. 2012 Dec;207(6):478.e1-7. doi: 10.1016/j.ajog.2012.09.029. Epub 2012 Oct 1.

3.

Vannucci RC

Current and potentially new management strategies for perinatal hypoxic-ischemic encephalopathy. Pediatrics. 1990 Jun;85(6):961-8.

4. Robertson CM, Perlman M. Follow-up of the term infant after hypoxic-ischemic encephalopathy. Paediatr Child Health. 2006 May;11(5):278-82.

5. Lawn JE, Kinney M, Lee AC, Chopra M, Donnay F, Paul VK, Bhutta ZA, Bateman M, Darmstadt GL. Reducing intrapartum-related deaths and disability: can the health system deliver? Int J Gynaecol Obstet. 2009 Oct;107 Suppl 1:S123-40, S140-2. doi: 10.1016/j.ijgo.2009.07.021.

6. Lawn JE, Cousens S, Zupan J; Lancet Neonatal Survival Steering Team. 4 million neonatal deaths: when? Where? Why? Lancet. 2005 Mar 511;365(9462):891-900.

7. Gluckman PD, Wyatt JS, Azzopardi D, Ballard R, Edwards AD, Ferriero DM, Polin RA, Robertson CM, Thoresen M, Whitelaw A, Gunn AJ. Selective head cooling with mild systemic hypothermia after neonatal encephalopathy: multicentre randomised trial. Lancet. 2005 Feb 1925;365(9460):663-70.

8. Shankaran SLA, Ehrenkranz RA, Tyson JE, McDonald SA, Donovan EF, Fanaroff AA, Poole WK, Wright LL, Higgins RD, Finer NN, Carlo WA, Duara S, Oh W, Cotten CM, Stevenson DK, Stoll BJ, Lemons JA, Guillet R, Jobe AH, National Institute of Child Health and Human Development Neonatal Research Network: Whole-body hypothermia for neonates with hypoxic ischemic encephalopathy. N Engl J Med. 2005 Oct 13;353(15):1574-84.

9. Eicher DJ, Wagner CL, Katikaneni LP, Hulsey TC, Bass WT, Kaufman DA, Horgan MJ, Languani S, Bhatia JJ, Givelichian LM, Sankaran K, Yager JY. Moderate hypothermia in neonatal encephalopathy: effi cacy outcomes. Pediatr Neurol. 2005 Jan;32(1):11-7.

10. Azzopardi D, Strohm B, Edwards A, Dyet L, Halliday H, Juszczak E, Kapellou O, Levene M, Marlow N, Porter E, Thoresen M, Whitelaw A, Brocklehurst P, Group TS: Moderate hypothermia to treat perinatal asphyxial encephalopathy. N Engl J Med. 2009 Oct 1;361(14):1349-58. doi: 10.1056/NEJMoa0900854.

11. Shah PS. Hypothermia: a systematic review and meta-analysis of clinical trials. Semin Fetal Neonatal Med.2010 Oct;15(5):238-46. doi: 10.1016/j.siny.2010.02.003. Epub 2010 Mar 7.

12. Edwards A, Brocklehurst P, Gunn A, Halliday H, Juszczak E, Levene M, Strohm B, Thoresen M, Whitelaw A, Azzopardi D: Neurological outcomes at 18 months of age after moderate hypothermia for perinatal hypoxic ischaemic encephalopathy: Synthesis and meta-analysis of trial data. BMJ. 2010 Feb 9;340:c363. doi: 10.1136/bmj.c363.

13. Jacobs SE, Berg M, Hunt R, Tarnow-Mordi WO, Inder TE, Davis PG. Cooling for newborns with hypoxic ischaemic encephalopathy. Cochrane Database Syst Rev. 2013 Jan 31;1:CD003311. doi: 10.1002/14651858.CD003311.pub3.

14. Tagin MA, Woolcott CG, Vincer MJ, Whyte RK, Stinson DA. Hypothermia for neonatal hypoxic ischemic encephalopathy: an updated systematic review and meta-analysis. Arch Pediatr Adolesc Med. 2012 Jun 1;166(6):558-66.

doi: 10.1001/archpediatrics.2011.1772.

15. Shankaran S, Pappas A, McDonald SA, Vohr BR, Hintz SR, Yolton K, Gustafson KE, Leach TM, Green C, Bara R, Petrie Huitema CM, Ehrenkranz RA, Tyson JE,Das A, Hammond J, Peralta-Carcelen M, Evans PW, Heyne RJ, Wilson-Costello DE, Vaucher YE, Bauer CR, Dusick AM, Adams-Chapman I, Goldstein RF, Guillet R, Papile LA, Higgins RD; Eunice Kennedy Shriver NICHD Neonatal Research Network. Childhood outcomes after hypothermia for neonatal encephalopathy. N Engl J Med. 2012 May 31;366(22):2085-92. doi: 10.1056/NEJMoa1112066.

16. Gunn AJ, Gluckman PD, Gunn TR. Selective head cooling in newborn

infants after perinatal asphyxia: a safety study Pediatrics. 1998 Oct;102(4 Pt 1):885-92.

17. Jacobs S, Stewart $M$, Inder $T$ et al. ICE: the Australian cooling trial for hypoxic-ischemic encephalopathy-in hospital outcomes. Proceedings of the Hot Topics in Neonatology Conference. Washington DC, 2008. 
18. Simbruner G, Mittal R, Rohlman F, Muche R. European nEURO.network trial. Proceedings of the Hot Topics in Neonatology Conference. Washington DC, Dec 7-9 2008.

19. Erecinska M, Thoresen M, Silver IA. Effects of hypothermia on energy metabolism in Mammalian central nervous system. J Cereb Blood Flow Metab. 2003 May;23(5):513-30.

20. Busto R, Globus MY, Dietrich WD, Martinez E, Valdés I, Ginsberg MD. Effect of mild hypothermia on ischemia-induced release of neurotransmitters and free fatty acids in rat brain. Stroke. 1989 Jul;20(7):90410 .

21. Thoresen M, Satas S, Puka-Sundvall M, Whitelaw A, Hallström A, Løberg EM, Ungerstedt U, Steen PA, Hagberg H. Post-hypoxic hypothermia reduces cerebrocortical release of NO and excitotoxins. Neuroreport. 1997 Oct 20;8(15):3359-62.

22. Nakashima K, Todd MM. Effects of hypothermia on the rate of excitatory amino acid release after ischemic depolarization. Stroke. 1996 May;27(5):913-8.

\section{Globus MY, Alonso O, Dietrich WD, Busto R, Ginsberg MD. Glutamate release and free radical production following brain injury: effects of posttraumatic hypothermia. Neurochem. 1995 Oct;65(4):1704-11.}

24. Northington FJ, Graham EM, Martin LJ. Apoptosis in perinatal hypoxic-ischemic brain injury: how important is it and should it be inhibited? Brain Res Brain Res Rev. 2005 Dec 15;50(2):244-57. Epub 2005 Oct 10

25. Ohmura A, Nakajima W, Ishida A, Yasuoka N, Kawamura M,Miura S, et al. Prolonged hypothermia protects neonatal ratbrain against hypoxic-ischemia by reducing both apoptosis and necrosis. Brain Dev. 2005;27:517---26.

26. Edwards AD, Yue X, Squier MV, Thoresen M, Cady EB, Penrice J, Cooper CE, Wyatt JS, Reynolds EO, Mehmet H. Specific inhibition of apoptosis after cerebral hypoxia-ischaemia by moderate post-insult hypothermia. Biochem Biophys Res Commun. 1995 Dec 26;217(3):1193-9.

27. Xu L, Yenari MA, Steinberg GK, Giffard RG. Mild hypothermia reduces apoptosis of mouse neurons in vitro early in the cascade. J Cereb Blood Flow Metab. 2002 Jan;22(1):21-8.
28. Zhang, Z; Sobel, RA; Cheng, D; Steinberg, GK; Yenari, MA. (2001). "Mild hypothermia increases Bcl-2 protein expression following global cerebral ischemia. Brain Res Mol Brain Res. 2001 Nov 1;95(1-2):75-85. doi:10.1016/S0169-328X(01)00247-9.

29. Cornette L. Therapeutic hypothermia in neonatal asphyxia. Facts Views Vis Obgyn. 2012;4(2):133-9.

30. Wassink G, Gunn ER ${ }^{1}$, Drury PP, Bennet L, Gunn AJ. The mechanisms and treatment of asphyxial encephalopathy. Front Neurosci. 2014 Feb 27;8:40. doi: 10.3389/fnins.2014.00040. eCollection 2014.

31. Gunn AJ, Gunn TR, Gunning MI, Williams CE, Gluckman PD. Neuroprotection with prolonged head cooling started before postischemic seizures in fetal sheep. Pediatrics. 1998 Nov;102(5):1098-106.

32. Silveira RC, Procianoy RS. Hypothermia therapy for newborns with hypoxic ischemic encephalopathy. J Pediatr (Rio J). 2015 Nov-Dec;91(6 Suppl 1):S78-83. doi: 10.1016/j.jped.2015.07.004. Epub 2015 Sep 4.

33. Laptook AR, Shalak L, Corbett RJ. Differences in brain temperature and cerebral blood flow during selective head versus whole-body cooling. Pediatrics. 2001 Nov;108(5):1103-10.

34. Simbruner G, Haberl C, Harrison V, Linley $\mathrm{L}$, Willeitner AE. Induced brain hypothermia in asphyxiated human newborn infants: a retrospective chart analysis of physiological and adverse effects. Intensive Care Med. 1999 Oct;25(10):1111-7.

35. Azzopardi D, Robertson NJ, Cowan FM, Rutherford MA, Rampling M, Edwards AD. Pilot study of treatment with whole body hypothermia for neonatal encephalopathy. Pediatrics. 2000 Oct;106(4):684-94.

36. Thoresen M, Whitelaw A.

Cardiovascular changes during mild therapeutic hypothermia and rewarming in infants with hypoxicischemic encephalopathy. Pediatrics. 2000 Jul;106(1 Pt 1):92-9.

37. Battin MR, Dezoete JA, Gunn TR, Gluckman PD, Gunn AJ. Neurodevelopmental outcome of infants treated with head cooling and mild hypothermia after perinatalasphyxia. Pediatrics. 2001 Mar;107(3):480-4.

38. Shankaran S, Laptook A, Wright LL, Ehrenkranz RA, Donovan EF, Fanaroff AA, Stark AR, Tyson 
JE, Poole K, Carlo WA, Lemons JA, Oh W, Stoll BJ, Papile LA,Bauer CR, Stevenson DK, Korones $\mathrm{SB}, \mathrm{McDonald} \quad \mathrm{S}$ Wholebody hypothermia for neonatal encephalopathy: animal observations as a basis for a randomized,controlled pilot study in term infants.

Pediatrics. 2002 Aug;110(2 Pt 1):377-85.

39. Fugelseth D, Satas S, Steen PA, Thoresen M. Cardiac output, pulmonary artery pressure, and patent ductusarteriosus during therapeutic cooling after global hypoxia-ischaemia. Arch Dis Child Fetal Neonatal Ed. 2003 May; 88(3): F223-F228. doi: 10.1136/fn.88.3.F223
40. Zhou WH, Shao XM, Zhang XD, Chen C, Huang GY.

[Effects of hypothermia on cardiac function in neonates with asphyxia]. Zhonghua $\mathrm{Er} \mathrm{Ke} \quad \mathrm{Za}$ Zhi. 2003 Jun;41(6):460-2.

41. Biggar WD, Barker C, Bohn D, Kent G. Partial recovery of neutrophil functions during prolonged hypothermia in pigs. J Appl Physiol (1985). 1986 Apr;60(4):1186-9.

42. Thoresen M. Supportive care during neuroprotective hypothermia in the term newborn: adverse effects and their prevention. Clin Perinatol. 2008 Dec;35(4):74963, vii. doi: 10.1016/j.clp.2008.07.018.

\section{How to cite this article?}

Rabindran, Gedam DS. Therapeutic Hypothermia in Perinatal Asphyxia: Int J Pediatr Res 2016;3(2):124-129. doi:10.17511/ijpr.2016.i02.10. 